\title{
PEKERJAAN IBU MEMPENGARUHI PEMBERIAN MPASI DINI BAYI 0 - 6 BULAN
}

\author{
Diah Eka Nugraheni \\ Politeknik Kesehatan Kementerian Kesehatan Bengkulu, Jurusan Kebidanan, \\ Jalan Indragiri Nomor 03 Padang Harapan Kota Bengkulu \\ diah1234@gmail.com
}

\begin{abstract}
Early complementary feeding in Bengkulu is still highbased on data obtained from Bengkulu Profile Provinsi in 2012 the total of babies who are exclusively breastfed babies $417803(41 \%)$ of the 43953 , meaning there is 26.015 infants $(51 \%)$ were gets an earlycomplementary feeding. The problem of this study is the high incidence of giving extra food for baby before the baby is 6 months old. The purpose ofthis research was to determine the factor sassociated with Early complementary feeding in Sawah lebar Kota Bengkulu. Types of research is descriptive analytic method with the cross sectional study design. The population is mothers with infants aged 0-6 months which amounted to 279 babies. Samples were taken by using a Acciedental sampling technique as many as 164 babies. The results showed, work have $p$ value $=0.009$ with OR2.48, This indicates that the variable, work has $\mathrm{p}$ value $<0.05$ means significant relationship with the provision of early complementary feeding. Health workers are expected to conduct health education regarding appropriate supplemental feeding on the baby's mother.
\end{abstract}

Keywords: Work and early complementary feeding

\begin{abstract}
Abstrak: Pemberian makanan pendamping ASI di Bengkulu masih tinggi, berdasarkan data yang diperoleh dari Profil Provinsi Bengkulu pada tahun 2012 total bayi yang mendapatkan ASI eksklusif 417803 (41\%) dari 43 953, berarti ada 26,015 bayi (51\%) yang mendapat makan pendamping asi .Masalah penelitian ini adalah tingginya insiden memberikan makanan tambahan untuk bayi sebelum bayi berusia 6 bulan. Tujuan penelitian penelitian adalah untuk mengetahui faktor yang berhubungan dengan makanan pendamping asi dini di wilayah kerja puskesmas Sawah Lebar Kota Bengkul. Jenis penelitian ini adalah metode deskriptif analitik dengan rancangan cross sectional. populasi adalah ibu dengan bayi berusia 0-6 bulan yang sebanyak 279 bayi. Sampel diambil dengan menggunakan teknik g Acciedental sampling sebanyak 164 bayi. Hasil penelitian menunjukkan pekerjaan memiliki nilai $\mathrm{p}=0,009$ dengan OR2.48. Hal ini menunjukkan bahwa variable pekerjaan ibu memiliki nilai $\mathrm{p}<0,05$ berarti hubungan yang signifikan dengan pemberian awal makanan pendamping ASI. Petugas kesehatan diharapkan untuk melakukan pendidikan kesehatan tentang makan suplemen yang tepat pada ibu bayi.
\end{abstract}

Kata kunci: Pekerjaan Ibu dan makanan pendamping asi dini

Pola pemberian ASI tanpa makanan tambahan (ASI eksklusif) masih perlu ditingkatkan karena rata-rata lama pemberian ASI eksklusif masih dibawah 6 bulan yaitu ratarata selama 4 bulan, baik di daerah perkotaan maupun di perdesaan pemberian ASI ekslusif di Indonesia masih cukup rendah. Balita berumur 2-4 tahun yang memiliki riwayat mendapat ASI eksklusif selama 6 bulan hanya sebesar $(40,25 \%)$ dimana balita laki-laki berumur 2-4 tahun sebanyak $(39,45 \%)$, sedikit lebih rendah dari pada balita perempuan berumur 2-4 tahun yang mendapat ASI eksklusif. Sementara itu, sebanyak $(40,94 \%)$ balita berumur 2-4 tahun di daerah perkotaan mendapat ASI eksklusif, sedikit lebih banyak dari pada di daerah pedesaan sebanyak (39,58\%). Hal ini berarti lebih dari separuh balita berumur 2-4 tahun di Indonesia tidak mendapatkan ASI eksklusif, sehingga perlu adanya upaya untuk meningkatkan kesadaran orang tua khususnya ibu akan pentingnya ASI eksklusif 
bagi kesehatan dan perkembangan balita (Profil Kesehatan Anak 2012).

Berdasarkan data yang diperoleh dari Profil Profinsi Bengkulu tahun 2012 jumlah bayi yang diberikan ASI Esklusif adalah 17.803 bayi (41\%) dari 43.953 jumlah bayi yang ada di Propinsi Bengkulu, berarti ada 26.015 bayi $(51 \%)$ yang mendapat MP ASI dini. Sedangkan data yang diperoleh dari Profil Kota Bengkulu selama tahun 2010 cakupan ASI Esklusifnya adalah 55,3\% dan tahun 2011 terdapat peningkatan sebesar 1\% dan pada tahun 2012 jumlah cakupan ASI Ekslusif menurun cukup jauh yaitu 51,5\% atau sebesar 5\% (Profil Profinsi Bengkulu).

Cakupan ASI ekslusif yang tertinggi adalah Puskesmas Bentiring dengan jumlah cakupan $84,9 \%$ dan terendah adalah di puskesmas Sawah Lebar dengan cakupan 24,2\% (Profil Kota, 2012).

Penelitian yang dilakukan oleh Yulfira mengungkapkan bahwa pemberian MP ASI dini tidak lepas dari pandangan budaya yang dilakukan secara turun menurun, banyak hal yang melatar belakangi kenapa bayi cepatcepat diberikan MP ASI karena ibu menganggap bahwa bayinya tidak akan mudah kenyang jika cuma diberi ASI saja itu tidak cukup bagi bayinya. Bayi yang rewel disalah artikan sebagai permintaan anak akan makanan padat seperti pisang atau nasi. Menurut teori, ASI merupakan makanan yang sangat mudah diserap sehingga banyak bayi lapar kembali dalam 2 jam setelah menyusu dengan puas. Makanan lain selain ASI pada dasarnya mengenyangkan tapi sangat berbahaya bagi pencernaan bayi.

\section{BAHAN DAN CARA KERJA}

Jenis penelitian yang digunakan metode deskriptif analitik, dengan rancangan penelitian Cross Sectional. Populasi seluruh bayi usia 0-6 bulan yang berada di Wilayah Puskesmas Sawah lebar berjumlah 279 bayi. Pengambilan sample secara Acciedental Sampling dengan jumlah responden 164 ibu. Pengolahan Data untuk analisis bivariatdengan menggunakan uji statistik yaitu chi-square $\left(\mathrm{X}^{2}\right)$ yang diolah dengan sistem komputerisasi (tingkat kepercayaan
$95 \%, \alpha=0,05)$. Analisis multivariat digunakan untuk melihat variabel yang paling berhubungan dengan MP ASI DINI dengan mengunakan uji statistisk regresi logistik.

\section{HASIL}

Sebagian besar $(72,0 \%)$ responden yang bekerja untuk mencari nafkah dan meninggalkan bayinya selama bekerja.

\begin{tabular}{|c|c|c|c|c|c|c|c|}
\hline Tabel 1 & & $\begin{array}{l}\text { bungan } \\
\text { nberian } \\
\text { vah Lebs }\end{array}$ & $\begin{array}{r}\text { Pekerj } \\
\text { MP AS } \\
\text { ar Kota B }\end{array}$ & $\begin{array}{l}\text { aan } \\
\text { I Din } \\
\text { ngkul }\end{array}$ & $\begin{array}{l}\text { Ibu } \\
\text { ni di } \\
\text { lu }\end{array}$ & $\begin{array}{r}I \\
\text { Pusl }\end{array}$ & $\begin{array}{l}\text { Dengan } \\
\text { kesmas }\end{array}$ \\
\hline \multirow{3}{*}{ Pekerjaan } & \multirow{2}{*}{\multicolumn{3}{|c|}{ MP ASI Dini }} & \multirow{3}{*}{$\mathbf{F}$} & \multirow{3}{*}{$\%$} & \multirow{3}{*}{$P$} & \multirow{3}{*}{ OR } \\
\hline & & Ya & Tidak & & & & \\
\hline & $\mathbf{F}$ & $\%$ & F $\%$ & & & & \\
\hline Bekerja & 72 & 61,0 & 39,0 & 1181 & 100 & & \\
\hline $\begin{array}{l}\text { Tidak } \\
\text { bekerja }\end{array}$ & 17 & 37,0 & 63,0 & $46 \quad 1$ & 1000 &, 009 & 2,670 \\
\hline
\end{tabular}

Sebagian besar responden $(72,0 \%)$ bekerja diluar rumah untuk mencari nafkah dan sebagian besar ibu bekerja memberikan MP ASI dini (61\%) Hasil uji Chi-square dengan $p$ Value $=0,009$ berarti terdapat hubungan yang bermakna antara pekerjaan dengan pemberian MP ASI dini. Responden yang bekerja memiliki risiko 2,670 kali lebih berpeluang memberikan MP ASI dini kepada bayinya dari pada ibu yang tidak bekerja (OR 2.670).

\section{PEMBAHASAN}

Hasil penelitian menunjukkan ada hubungan yang bermakna antara pekerjaan dengan pemberian MP ASI dini $(p=0,009)$. Hal ini juga diperkuat oleh penelitian kristianto (2010) bahwa faktor pekerjaan juga dapat menjadi salah satu faktor yang mempengaruhi ibu dalam pemberian ASI secara ekslusif.

Dalam artikel Yohmi, E (2012) juga menguatkan hasil penelitian ini dengan menyebutkan bahwa sudah menjadi rahasia umum jika ASI merupakan makanan terbaik bagi bayi khususnya sampai sikecil berusia enam bulan. Namun yang kerap menjadi permasalahanya bagaimana bagi ibu yang bekerja tapi tetap ingin memberi ASI pada buah hatinya, Berikan ASI sebanyak mungkin. Karena justru selama cuti kehamilan, 
ibu justru mulai mencoba-coba mencampur susu formula supaya nanti bayinya tidak kaget.Padahal, menyusui secara eksklusif dan sering selama cuti melahirkan justru bisa memperbanyak produksi ASI.

\section{KESIMPULAN}

Hasil penelitian disimpulkan bahwa adanya hubungan antara pekerjaan dengan pemberikan makanan pendamping ASI secara dini pada bayi usia 0-6 bulan di Puskesmas Sawah Lebar Kota Bengkulu

Diharapkan untuk mengadakan penyuluhan kesehatan mengenai pemberian makan

\section{DAFTAR RUJUKAN}

Arikunto, S.. 2010. Pendidikan dan Perilaku Kesehatan. Jakarta : Rineka Cipta

Baskoro,anton,2008.ASI Panduan Praktis Ibu Menyusui.yogyakarta : Bayu Media

Depkes RI. Ibu Berikan ASI Eksklusif Baru Dua Persen. Jakarta. 2004

Krisnatuti, Diah. 2008. Menyiapkan Makanan Pendamping Asi. Jakarta : Puspa Swara

Kristianto, yonathan.2012. Analisis Faktor Yang Mempengaruhi Perilaku Ibu Dalam Pemberian Makanan Pendamping ASI Terlalu Dini Di Posyandu Mawar I Desa Karangrejo. Jurnal Penelitian: Kediri. Diakses pada tanggal 25-09-2013

Media, Yulfrida.2005. Faktor-Faktor Sosial Budaya Yang Melatarbelakangi Pemberian MPASI Dini. Jurnal kesehatan: Lombok. Diakses pada tanggal 02-10-2013 tambahan yang tepat pada bayi ibu, penyuluhan dapat dilakukan dengan bekerja sama dengan tim gizi yang ada di puskesmas, dengan diadakan penyuluhan secara rutin maka diharapkan adanya peningkatan pengetahaun ibu dan juga dapat menurunkan motivasi ibu dalam pemberian MP ASI DINI. Serta penyuluhan mengenai resiko yang ditimbulkan jika bayi diberikan makan pendamping asi terlalu dini juga penting karena terlihat bahwa pengetahuan responden juga masih rendah mengenai hal tersebut.

Padang, Asdani.2007.Analisa Faktor-Faktor Yang Mempengaruhi Ibu Dalam Pemberian MP ASI Dini. Tesis : Tapanuli Tengah. Diakses pada tanggal 25-09-2012

Profil Anak. 2012. Profil Anak Indonesia. Jakarta : CV. Miftahur Rizky. Diakses pada tanggal 0110-2013

Rusli, Utami. 2005. ASI Eksklusif. Jakarta : CV. Pustaka Pembangunan Swadaya Nusantara.

Soraya, Luluk.2006. Resiko Pemberian MPASI Terlalu Dini. 2006

Sulistyoningsih, Haryani. 2011. GiziUntukKesehatanIbudanAnak.Yogyakarta :Grahallmu.

Riskani, Ria.2012. Keajaiban ASI. Jakarta Timur: Dunia Sehat 